\title{
STAN I PERSPEKTYWY PUBLIKACJI KOŚCIELNYCH AKT WIZYTACYJNYCH Z OKRESU STAROPOLSKIEGO
}

\section{Wprowadzenie}

Przed niemal 50. laty, ks. prof. Stanisław Librowski, napisał we wstępie do opracowania dotyczącego wizytacji w diecezji włocławskiej: „Spośród wielu zespołów i grup akt archiwów kościelnych bez wątpienia pierwsze miejsce jako źródła historyczne zajmują wizytacje kościołów i parafii. Poruszając całokształt życia religijno-duszpasterskiego, wizytacje stanowią wszechstronne źródło do dziejów parafii. Ponieważ, dalej, wspomniane wizytacje były przeprowadzane na ogół regularnie, i to w całym świecie katolickim, dostarczają one ważnych, o charakterze niemal powszechnym i wielowarstwowym, źródeł do historii nie tylko kościelnej, poszczególnych parafii, diecezji i kościołów"1. Dlatego też ilekroć rozpoczynamy badania dotyczące dziejów instytucji kościelnych w okresie staropolskim, tylekroć przychodzi nam sięgać, niemal w każdym przypadku, do rękopisów wizytacji kościelnych. Ich wartość jest nieustannie podkreślana przez historyków czerpiących informacje $\mathrm{z}$ bogactwa treści tego rodzaju dokumentacji ${ }^{2}$.

Wprowadzając pewną systematykę rozważań warto przypomnieć, że wizytacje kanoniczne instytucji i osób z nimi związanych sięgają swoją metryką wczesnego chrześcijaństwa. Podlegając różnorakim zmianom formalnym czy też przyjmując nowy charakter, odgrywały ważną rolę w administracji Kościoła śred-

* Ks. Tomasz Moskal - dr historii Kościoła, adiunkt w Instytucie Historii Kościoła i Patrologii, Wydział Teologii KUL.

${ }^{1}$ S. Librowski, Wizytacje diecezji włocławskiej, cz. 1. Wizytacje diecezji kujawskiej i pomorskiej, t. 1. Opracowanie archiwalno - źródtoznawcze, „Archiwa Biblioteki i Muzea Kościelne” [dalej: ABMK], 6 (1964) s. 7.

${ }^{2}$ S. Litak, Akta wizytacyjne parafii z XVI-XVIII wieku jako źródto historyczne, „Zeszyty Naukowe Katolickiego Uniwersytetu Lubelskiego" [dalej: Zeszyty Naukowe KUL], 5 (1962) nr 3, s. 41-58; H. E. Wyczawski, Wprowadzenie do studiów w archiwach kościelnych, Kalwaria Zebrzydowska 1989, s. 256-260; S. Litak, Parafie w Rzeczypospolitej w XVI-XVIII wieku, Lublin 2004, s. 29-30. 
niowiecznego ${ }^{3}$. Po kryzysie z początku XVI w., w uchwałach Soboru Trydenckiego na sesji 24 z 11 listopada 1563 w kanonie 3 zapisano: „Gdyby patriarchowie, prymasi, metropolici i biskupi nie zadbali osobiście o przeprowadzenie wizytacji swej własnej diecezji, albo gdyby na drodze stanęła im jakaś zgodna z prawem przeszkoda, to wówczas dokonają jej za pośrednictwem swego wikariusza generalnego czy też wizytatora"4. Przypomniane zostały również duszpasterskie założenia wizytacji: „Głównym zaś celem tych wszystkich wizytacji będzie wprowadzenie zdrowej i czystej nauki katolickiej, wypędzenie herezji, zachowanie dobrych obyczajów a poprawa złych, zachęcenie i umocnienie ludu w pobożności przez namowy i upomnienia, utwierdzenie w pokoju i prawości, a także wydanie innych owoców wśród wiernych, stosownie do miejsca, czasu i możliwości, wedle roztropności wizytatorów"s. Co jest natomiast istotnym dla archiwistów i historyków ,archidiakoni albo niżsi od nich dostojnicy są obowiązani, aby po dokonaniu wizytacji w okresie jednego miesiąca zdali sprawozdanie oraz przedstawili biskupowi zeznania świadków i kompletne akta wizyt".

Uchwały Soboru Trydenckiego określając osoby uprawnione do wizytowania, wygenerowały podział czynności z tym związanych na realizowane osobiście przez biskupa lub jego delegatów. W ramach swoich obowiązków mieli ich dokonywać ponadto archidiakoni i dziekani w podległych im obszarach organizacji terytorialnej Kościoła. $Z$ kolei ze względu na zakres, mamy do czynienia z protokołami wizytacji wewnętrznych i zewnętrznych oraz tych, które są połączeniem wyżej wymienionych rodzajów ${ }^{7}$. Ta, określona przez uchwały Soboru Trydenckiego, działalność duszpasterzy, przyniosła niezwykle bogaty materiał źródłowy do dziejów życia religijnego w okresie staropolskim.

\section{Rozproszenie akt wizytacyjnych}

Jednakże, nawet pobieżne przejrzenie inwentarzy archiwalnych i katalogów bibliotecznych, pozwala stwierdzić rozproszenie zachowanych akt wizytacyjnych. Wynikło to chociażby z rodzaju wizytacji i osoby wizytatora, przez co akta trafiały, w wielkim uproszczeniu, czy to do archiwum kapitulnego czy diecezjalnego. Niemałą rolę w rozproszeniu tego rodzaju archiwaliów odegrały również zmiany w organizacji terytorialnej Kościoła na ziemiach polskich. Wydarzenia polityczne często implikowały erygowanie nowych diecezji lub korektę granic starych, przez co przyczyniały się do dekoncentracji materiałów archiwalnych. Tytułem egzemplifikacji można tu spojrzeć na protokoły powizytacyjne z terenów diecezji

${ }^{3}$ S. Litak, $W$ sprawie publikowania i rejestracji akt wizytacyjnych kościołów i parafi, ABMK 14 (1967) s. 133-134.

${ }^{4}$ Sobór Trydencki, Sesja 24: II, Kanon 3: Zasady przeprowadzania wizytacji przez przetożonych, w: Dokumenty soborów powszechnych, T. IV: Lateran V. Trydent. Watykan I., opr. A. Baron, H. Pietras, Kraków 2004, s. 739.

${ }^{5}$ Tamże.

${ }^{6}$ Tamże.

${ }^{7}$ S. Litak, W sprawie, s. 134-135. 
krakowskiej w jej przedrozbiorowych granicach, których w krakowskim archiwum zachowało się około 120 . W tym miejscu ich przegląd zacieśnimy tylko do archidiakonatu sandomierskiego.

W Archiwum Kapituły Krakowskiej przechowywano akta wizytacji z lat $1604^{8}$ i $1614^{9}$. Archiwum Kurii Metropolitalnej w Krakowie posiada w swoim zasobie protokoły akt z lat $1604^{10}, 1646^{11}, 1727^{12}, 1737-1738^{13}, 1748^{14}, 1764-$ $1765^{15}$. Archiwum Kapituły Katedralnej w Sandomierzu jest właścicielem wi-

${ }^{8}$ Archiwum Kurii Metropolitalnej w Krakowie [dalej: AKMK], sygn. AVCap 23, Acta visitationis ecclesiarum archidiaconatus Sandomiriensis sub. R.D. Bernardo Maciejowski, episcopo Cracoviensi, duce Severiensi. Exequutio visitationis peragebatur Sendomiriae die 16 Martii ad 3 Aprilis a. D. 1604.

${ }^{9}$ AKMK, sygn. AVCap 36, Visitatio ecclesiarum in decanatibus Sandomiriensi, Polanecensi, et Rudnicensi ad archidiaconatum Sandomiriensem pertinentium per Albertum Gniewicz a.D. 1614 peracta.

${ }^{10}$ AKMK, sygn. AV 4, Liber continens decreta executiva visitationum et alia correctionem et reformationem Vita et morum cleri pertinentia tempore Fel. Rec. R.D. Bernardi Maciejowski Cardinalis et episcope Cracoviensis ac ducis Severiensis conscripta ex annis 1601 et sequent... Exequutio visitationis anno Domini 1604 - ecclesiae et clerus decanatus Rudnicensis, Miechocinensis, Połanecensis, Coprivnicensis, ecclesiae collegiatae Sandomiriensis clerus et ministry anno Domini $1604, k .58 v-72$.

${ }^{11}$ AKMK, sygn. AV 7, Visitatio Sandomieriensis Archidiaconatus a.D. 1646 ex commisione R.D. Petri Gembicki, episcope Cracoviensis, ducis Severiae per Gregorium Kownacki, IUD, custodem Tarnoviensem, Venceslaum kostecki, praepositum Opocnensem, plebanum Malicensem expedita.

${ }^{12}$ AKMK, sygn. AV- 22, Visitatio realis et personalis ecclesiarum, parochialium, hospitalium, capellarum, altarium et confraternitatum in quatuor decanatibus archidiaconatus Sandomieriensis, Videlicet: Rudnicensi, Miechocinensi, Coprivnicensi, et Polanecensi existentibus, sub fel. auspiciis Cel. Principis R.D. Constantini Feliciani in Szaniawy Szaniawski, episkopi Cracoviensis, ducis Severiae per me Dominikum Lochman VID, canonicum cathedralem Cracoviensem, archidiaconum Sandomieriensem a.D. 1727 diebus primis mensis Martii inchoata, tandem mensae Septembri finaliter expedita.

${ }^{13}$ AKMK, sygn. AV - 25, Visitatio archidiaconatus Sandomieriensis, scilicet quatuor decanatuum: Coprivnicensis, Polanecensis, Rudnicensis et Miechocinensis, ex speciali commissione Eminentissimi S.R.E. Cardinalis praesbiteri R.D. Joannis Alexandri in Lipie Lipski, episkopi Cracoviensis, ducis Severiae per me Andream Potocki, cathedraelem Chelmensem, Sandomieriensem canonicum, praepositum Siennensem etc. inchoata anno 1737, continua et expedita 1738.

${ }^{14}$ AKMK, sygn. AV - 42, Acta visitationis in decanatibus Rudnicensi et Miechocinensi sub auspiciis et regimine Cel. R.D. Andreae Stanislai Kostka comitis in Załuskie Zatuski, episcopi Cracoviensis, ducis Severiae, per me Andream Potocki canonicum ecclesiarum cathedralium Chelmensem et coadiutorem Cracoviensem archidiaconum et officialem Sandomieriensem, expeditae diebus Januarii, Februarii et Martii a.D. 1748.

${ }^{15}$ AKMK, sygn. AV - 51, Acta visitationis ecclesiarum in archidiaconatu Sandomieriensi consistentium de speciali mandato Cel. Principis R.D. Cajetani Ignatii Soltyk, episcopi Cracoviensis, ducis Severiae, per me Joannem Cantium Ligęza STD, ecclesiarum Insignis Collegiatae Sandomieriensis archidiaconum in Trójca curatum expeditae a.D. 1764 inchoatae annisque sequentibus 1765 et 1766 terminatae. 
zytacji z $1676^{16}, 1694^{17}$ oraz dla dekanatu koprzywnickiego z $1791^{18}$. Ponadto z 1650 pochodzą inwentarze sprzętów parafialnych sporządzone w czasie wizytacji archidiakona Sebastiana Kokwińskiego ${ }^{19}$. Dział rękopisów w Bibliotece Seminarium Duchownego w Sandomierzu zawiera kopie krakowskich protokołów wizytacyjnych z lat $1727^{20}, 1764-1765^{21}$, jak również wizytację dekanatów połanieckiego, koprzywnickiego, opatowskiego i zawichojskiego (brakuje miechocińskiego i rudnickiego które w 1772 znalazły się pod zaborem austriackim) z $1782^{22}$. Ponadto $w$ teczkach poszczególnych parafii znajdują się unikatowe odpisy z wizytacji, których nie znajdujemy w dotychczas wymienionych. Można tu wskazać chociażby parafie Chobrzany ${ }^{23}$ czy Osiek $^{24}$, gdzie wśród dokumentów parafialnych znajdują się kopie tekstów wizytacji. To samo dotyczy Archiwum Archidiecezji Przemyskiej. W teczkach parafii dekanatów miechocińskiego i rudnickiego z okresu staropolskiego, znajdujemy szereg luźnych dokumentów zawierających odpisy akt wizytacyjnych. Jako egzemplifikację wskazać można parafię Racławice, gdzie w poszycie zawierającym dokumenty parafialne $\mathrm{z}$ lat 1440-1849 znajdujemy unikatowy wyciąg z akt wizytacji dokonanej przez kanonika sando-

${ }^{16}$ Archiwum Kapituly w Sandomierzu [AKapS], sygn. 798, Visitatio externa archidiaconatus Sandomieriensis authoritate et speciali mandato illustrissimi ac reverendissimi principis domini, domini Andreae Trzebicki Dei et Apostolicae Sedis gratia episcopi Cracoviensis, ducis Severiae, per me Martinum Mozgawa, canonicum Sandomieriensem anno Domini 1676, mense Septembri inchoata, In Decembri vero mense Expedia; sygn. 799, Visitatio interna archidiaconatus Sandomieriensis authoritate et speciali mandato illustrissimi ac reverendissimi principis domini, domini Andreae Trzebicki Dei et Apostolicae Sedis gratia episcopi Cracoviensis, ducis Severiae, per me Martinum Mozgawa, canonicum Sandomieriensem anno Domini 1676, mense Septembri inchoata, In Decembri vero mense Expedia

${ }^{17}$ AKapS, sygn. 800, Visitationes internae et externae decanatuum Koprzywnicensis, Rudnicensis, Mechocinensis, Polanecensis ecclesiarum, XLII hospitalium peractae per archidiakonem Sandomieriensem Anno Domini MDCXCIV, mense Septembri, Octobri, Novembri.

${ }^{18}$ AKapS, sygn. 802, Protokoty powizytacyjne kościołów dekanatu koprzywnickiego.

${ }^{19} \mathrm{AKapS}$, sygn. 797, Inwentarze naczyń, szat i innych paramentów kościołów $w$ archidiakonacie sandomierskim.

${ }^{20}$ Biblioteka Wyższego Seminarium Duchownego w Sandomierzu [dalej: BWSDwS], sygn. J 1440, Visitatio realis et personalis ... archidiaconatus Sandomiriensis, videlicet: rudnicensi, michocinensi, coprivnicensi et połanecensi per Dominicum Lochman.

${ }^{21}$ BWSDwS, Dział rękopisów, sygn. J 1450, Protokoły, wizytacje archidiakonatu sandomierskiego.

${ }^{22}$ BWSDwS, Dział rękopisów, sygn. J 1476, Protokół wizyty generalnej 4 dekanatów koprzywnickiego, połanieckiego, zawichojskiego, opatowskiego odprawiony z rozrzadzenia Jaśnie Oświeconego Książęcia Imci Poniatowskiego, biskupa Ptockiego, koadiutora z zupetna jurysdykcja, krakowskiego ksiazżęcia Siewierskiego, orderów Orła Białego i S. Stanistawa kawalera, roku 1782. Przez W. J. X. Stanisława Ptaszyńskiego, kanonika katedralnego Inflanckiego, proboszcza Nowomieyskiego.

${ }^{23}$ BWSDwS, Dział rękopisów, sygn. G 1159, Dokumenty kościoła i parafii w Chobrzanach z lat 1604-1888 (odpisy protokołów z wizyt kanonicznych).

${ }^{24}$ BWSDwS, Dział rękopisów, sygn. R 1922, Wizytacje kościoła parafialnego w Osieku z lat: $1748,1761,1823 / 1824$. 
mierskiego Marcina Głoszkowskiego z 16 lutego $1761^{25}$. Nie jest to oczywiście pełen zestaw archiwów w których można znaleźć odpisy protokołów wizytacyjnych. Na przebadanie czekają jeszcze chociażby Archiwum Diecezjalne w Sandomierzu czy też archiwa parafialne.

\section{Stan publikacji}

Wskazano wyżej na rozproszenie interesujących nas archiwaliów. Pomimo tego przeglądając dorobek naukowy historyków zajmujących się okresem staropolskim można bez przesady stwierdzić, że protokoły powizytacyjne zajmują poczesne miejsce $\mathrm{w}$ ich pracach. Tylko w ostatnich latach ukazały się źródłowe edycje wizytacji diecezji katolickich ${ }^{26}$ i protestanckich ${ }^{27}$. W myśl postulatów S. Librowskiego i S. Litaka, publikowane są repertoria ksiąg zawierających protokoły powizytacyjne ${ }^{28}$. W różnorodnych czasopismach naukowych ukazują się edycje tekstów wizytacji pojedynczych parafii czy innych instytucji kościelnych ${ }^{29}$. Znane są wydawnictwa w których drukowano streszczenia lub thumaczenia wizytacji ${ }^{30}$.

$\mathrm{Z}$ racji bogactwa informacji źródłowych zawartych w protokołach wizytacyjnych, stanowią one podstawę do wieloaspektowych rozważań. Uwzględniając zaprezentowane powyżej archiwalia dotyczące archidiakonatu sandomierskiego, zrealizowano w tym względzie badania nad siecią parafialną ${ }^{31}$, duchowień-

${ }^{25}$ Archiwum Archidiecezji Przemyskiej, sygn. A. D. 1476, Dokumenty parafii Ractawice z lat 1440-1849; 16 II 1761, Wyciag z aktów wizytacji kanonika sandomierskiego ks. Marcina Głoszkowskiego, s. 39-50.

${ }^{26}$ Akta wizytacji generalnej diecezji inflanckiej i kurlandzkiej czyli piltyńskiej z 1761 roku, wyd. S. Litak, Torun 1998; Protokoły wizytacyjne dekanatu bytomskiego z lat 1792-1793, wyd. J. Pater, Poznań - Wrocław 2003.

${ }^{27}$ Wizytacja biskupstwa sambijskiego z 1569 roku, wyd. J. Wijaczka, Toruń 2001.

${ }^{28}$ W. Kujawski, Repertorium ksiag wizytacji kanonicznych biskupów kujawsko-pomorskich przechowywanych w Archiwum Diecezjalnym w Pelplinie, cz. 1, ABMK 84 (2005), s. 93-236, cz. 2., tamże, 85 (2006), s. 149-304, cz. 3., tamże 91 (2009), s. 119-269.

${ }^{29}$ Wizytacja parafii Sulisławice w 1782 r., w: Historia świadectwem czasów, red. W. Bielak, S. Tylus, Lublin 2006, s. 347-359.

${ }^{30}$ Kot S., Szkolnictwo parafialne w Matopolsce w XVI - XVIII w., Lwów 1912. Na stronach 219-224 archidiakonat sandomierski.

${ }^{31}$ S. Jop, Sieć parafialna archidiakonatu sandomierskiego do końca XVI w., Sprawozdania Towarzystwa Naukowego KUL 7 (1958), s. 154 - 158; J. Rawski, Podziat archidiakonatu sandomierskiego na dekanaty, Kronika Diecezji Sandomierskiej 51 (1958), s. 231 - 240, 310 - 314. 
stwem $^{32}$, uposażeniem parafii ${ }^{33}$, stosunkami religijno-społecznymi ${ }^{34}$, bractwami ${ }^{35}$, szkolnictwem $^{36}$, szpitalnictwem ${ }^{37}$, bibliotekami ${ }^{38}$, organami ${ }^{39}$. Wyliczenie zrealizowanych obszarów badawczych wykorzystujących protokoły wizytacyjne dla jednej tylko jednostki terytorialnej Kościoła (a trzeba pamięta, że nie wszystkie wymienione archiwalia były znane autorom tych opracowań), potwierdza ich wartość i ważność dla nauki polskiej.

Tym niemniej ,akta wizytacyjne stanowią dziś wprost bezcenny materiał informacyjny, który w dalszym ciągu, mimo licznych postulatów nie został jeszcze włączony w zadowalającym stopniu w obieg naukowych badań. Nadal wiele protokołów wizytacyjnych pozostaje w rękopisach, często nieznanych lub zapomnianych albo świadomie pomijanych ze względu na trudno czytelny zapis" ${ }^{\prime 20}$.

\section{Perspektywy publikacji protokolów wizytacyjnych}

Podejmowane od lat wieloaspektowe badania nad wizytacjami kościelnymi mają pokaźny dorobek. Można się o tym przekonać z powyższej egzemplifikacji bądź podczas przeglądania chociażby Bibliografii Historii Polskiej. Tak jak w przypadku oryginalnego materiału źródłowego jakim są wizytacje, tak również ich publikacje drukowane opatrzone często fantastycznym komentarzem w postaci aparatu naukowego, mają charakter materiału rozproszonego. Czy nie nad-

32 J. Szczepaniak, Duchowieństwo archidiakonatu sandomierskiego w 1748 r., Studia Sandomierskie [dalej: SS], 16 (2009), z. 3-4, s. 5-38.

${ }^{33}$ W. Kowalski, Uposażenie parafii archidiakonatu sandomierskiego $w$ XV-XVIII wieku, Kielce 1998.

${ }^{34}$ W. Kowalski, Ludność archidiakonatu sandomierskiego w połowie XVII wieku, w: Rzeczypospolita w okresie potopu, pod red. J. Muszyńskiej i J. Wijaczki, Kielce 1996; tenże, Ludność żydowska a duchowieństwo archidiakonatu sandomierskiego $w$ XVII-XVIII wieku, Studia Judaistica 2 (1988), s. 177-199.

${ }^{35} \mathrm{G}$. Marciniak, Bractwa religijne w archidiakonacie sandomierskim od połowy XVI w. do rozbiorów Polski (na podstawie wizytacji kościelnych), Lublin 1991 (mps Archiwum KUL).

${ }^{36}$ A. Zapart, Szkolnictwo parafialne $w$ archidiakonacie sandomierskim $w$ XVI-XVIII wieku, Roczniki Teologiczno - Kanoniczne 25 (1978), z. 4, s. 47-49; tenże, Sieć szkół parafialnych warchidiakonacie sandomierskim od XVI do XVIII w., tamże 27 (1980), z. 4, s. 57 - 75; tenże, Uczniowie szkót parafialnych $w$ dawnym archidiakonacie sandomierskim, SS 3 (1982), s. 465 - 480; tenże, Podstawy materialne szkót parafialnych $w$ archidiakonacie sandomierskim $w$ XVI-XVIII w., tamże 6 (1990-1996), s. 518-532.

${ }^{37}$ W. Wójcik, Z dziejów kościelnego szpitalnictwa - archidiakonat sandomierski, Ateneum Kapłańskie 51 (1949), s. 265 - 274; W. Kowalski, Szpitale i dobroczynność w archidiakonacie sandomierskim, w: Charitas. Miłosierdzie i opieka społeczna $w$ ideologii, normach postępowania i praktyce społeczności wyznaniowych XVI-XVIII wieku, pod red. U. Augustyniak i A. Karpińskiego, Warszawa 1999, s. 167-186.

${ }^{38}$ T. Moskal, Biblioteki parafialne $w$ archidiakonacie sandomierskim $w$ XVIII wieku, Sandomierz 2005.

${ }^{39}$ M. Konopka, Organy $w$ archidiakonacie sandomierskim $w$ XVIII wieku (na podstawie akt wizytacyjnych), Organy i Muzyka 5 (1984), s. 57-70.

${ }^{40}$ Protokoly wizytacyjne, s. 9-10. 
szedł więc czas na realizację projektu, który miałby jako cel zgromadzenie informacji o protokołach wizytacyjnych poszczególnych parafii na ziemiach polskich w okresie przedrozbiorowym? Mógłby on przyjąć następujący układ:

— instytucja (parafia, kolegiata, klasztor).

- miejsce przechowywania, sygnatura, tytuł zespołu, strony lub karty. W przypadku publikacji źródła należałoby podać dane bibliograficzne.

- opracowania drukowane w których zostały wykorzystane informacje zawarte $\mathrm{w}$ wymienionych protokołach wizytacyjnych

W ten sposób uwzględniono by zostały nie tylko całe księgi wizytacyjne, ale również zachowane pojedyncze odpisy powizytacyjne. Taka baza danych ułatwiłaby w znaczący sposób orientacje nad zasobem archiwalnym w tym względzie. Ponadto jawi się pytanie, czy nie wartałoby pokusić się o przygotowanie bibliografii dotyczącej problematyki wizytacji kościelnych? W połączeniu z bazą danych ukazanie dotychczasowego dorobku naukowego w tym zakresie byłoby doskonałym narzędziem w pracy naukowej badaczy zajmujących się tą problematyką. Ponadto zrobiono by kolejny znaczący krok w kierunku skompletowania informacji o jednym z najcenniejszych rodzajów źródeł do dziejów Kościoła w Polsce przedrozbiorowej. 